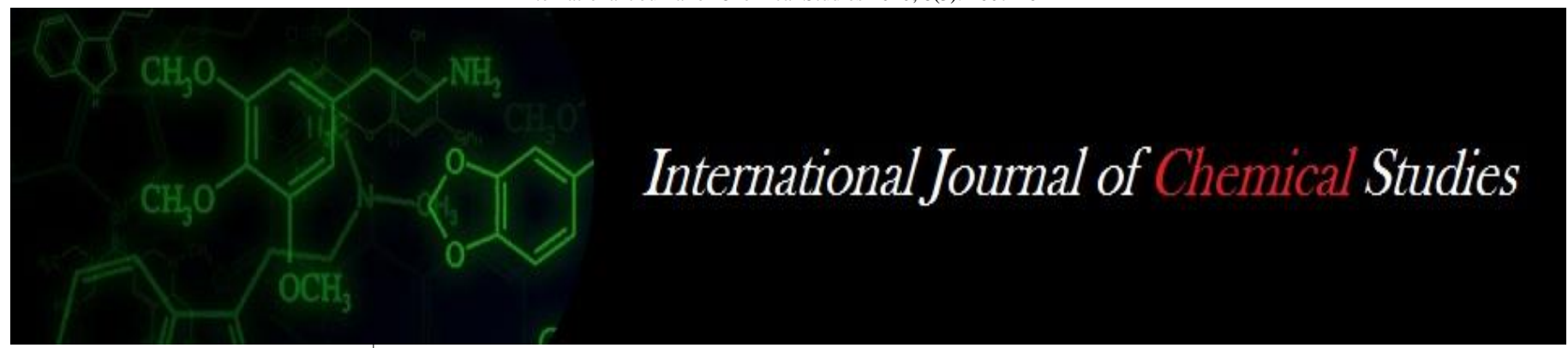

P-ISSN: 2349-8528

E-ISSN: 2321-4902

www.chemijournal.com

IJCS 2020; 8(3): 2607-2612

(C) 2020 IJCS

Received: 01-03-2020

Accepted: 04-04-2020

Bijay Kumar Baidya

Department of Fruit Science and

Horticulture Technology, College

of Agriculture, OUAT,

Bhubaneswar, Odisha, India

Suhrita Chakrabarty

Professor, Department of Post

Harvest Technology, Faculty of

Horticulture, AICRP on

Floriculture, Bidhan Chandra

Krishi Viswavidyalaya,

Mohanpur, Nadia, West Bengal,

India

Priyanjani Sethy

Department of Floriculture and

Landscaping, College of

Agriculture, OUAT,

Bhubaneswar, Odisha, India

Corresponding Author: Bijay Kumar Baidya

Department of Fruit Science and Horticulture Technology, College of Agriculture, OUAT,

Bhubaneswar, Odisha, India

\section{Extending shelf life of loose tuberose florets (Polianthes tuberosa Linn. cv. Prajwal) by quick dipping in boric acid and sodium benzoate followed by low temperature storage}

\author{
Bijay Kumar Baidya, Suhrita Chakrabarty and Priyanjani Sethy
}

DOI: https://doi.org/10.22271/chemi.2020.v8.i3al.9606

\begin{abstract}
The present experiment was conducted in the laboratory of AICRP on Floriculture, Directorate of Research Complex, Kalyani, Bidhan Chandra Krishi Viswavidyalaya, Mohanpur, Nadia, West Bengal to study the effect of boric acid and sodium benzoate for improving post-harvest life of loose flowers of tuberose cv. Prajwal. The flowers were dipped (5 seconds Quick dip) in different chemicals viz., Boric acid $(2 \%, 3 \%, 4 \%$, and $5 \%)$ and Sodium benzoate $(10 \mathrm{ppm}, 25 \mathrm{ppm}$, and 50ppm) followed by packing in 50 gauge zip-locked polyethylene packaging $(0.34 \%$ ventilation) and stored at refrigerated conditions $\left(6.5 \pm 5^{\circ} \mathrm{C}\right.$ and relative humidity $\left.-40-55 \%\right)$. The control set was kept at ambient storage conditions. The experiment was conducted in a completely randomized block design with three replications. The results showed that flowers treated with sodium benzoate 50ppm (T8) exhibited maximum shelf life (7 days), minimum loss of fresh weight, and the highest proportion of fresh flowers with greater acceptability over $\mathrm{T} 1$ (only refrigerated) i.e. 3.83 days and $\mathrm{T} 9$ (control) i.e. 1.4 days.
\end{abstract}

Keywords: Boric acid, sodium benzoate, polyethylene packaging, storage, shelf life, acceptability, and tuberose

\section{Introduction}

Tuberose (Polianthes tuberosa L.) is one of the most important bulbous ornamentals of humid tropics and is highly valued for loose as well as cut flowers. It belongs to family Amaryllidaceae and originated from Mexico. They are valued a whole lot by the aesthetic world for their beauty and fragrance. The flowers are appealing and elegant in appearance with a sweet fragrance and in great demand for indoor decoration, garlands, bouquets, cut flower trade and extraction of oil. Among different cultivars existing, Prajwal is an important single variety cultivar that evolved through hybridization released from IIHR, Bangalore in 1990 (one among the low cost high yielding varieties developed by IIHR). It is the result of cross between 'Shringar' and 'Mexican Single'. It bears single type flowers on tall stiff spikes. The flower buds are slightly pinkish in colour while the flowers are pure white yielding about 15.5$18 \mathrm{t}$ loose flowers $/ \mathrm{ha} / \mathrm{yr}$. Tuberose flowers are incredibly perishable, unlike other horticultural or agricultural crops. Due to poor keeping quality, the post-harvest losses in tuberose are significantly higher than any other crop. It is estimated that about $20 \%$ loss of tuberose occurs during the marketing only. Due to their extremely perishable nature, proper treatment is required to maintain the quality of tuberose (Hardenburg, 1990) ${ }^{[6]}$. Keeping this in mind, a study was undertaken to enhance the shelf life of Tuberose flowers by dipping them in Boric acid and Sodium benzoate solution at different concentrations followed by packing and storage in simple refrigerated condition.

\section{Materials and Methods}

The present investigation was undertaken under the department of Post Harvest Technology of Horticultural crops under the Faculty of Horticulture during the year 2017-18. The laboratory work was carried out in the laboratory of AICRP on Floriculture, Directorate of Research Complex, Kalyani, Bidhan Chandra Krishi Viswavidyalaya, Mohanpur, Nadia, and West Bengal. 
For the experiment loose tuberose of cv. Prajwal was collected from an experimental plot of Mondouri, Horticultural research station, Nadia, West Bengal. The experimental plots were well prepared by repeated tilling and application of organic manure $\left(@ 5 \mathrm{~kg} / \mathrm{m}^{2}\right)$ and inorganic fertilizer (N: P: K @ 100: 100: 150). For packaging of the tuberose flowers, 7 X 10-inch sized polyethylene zip-locked bags of 50-gauge thickness were used.

Uniform $20 \mathrm{~g}$ freshly harvested flowers of uniform-sized flowers were separated from the spikes early morning and were given quick dip treatment with the chemicals solutions i.e.boric acid $(2 \%, 3 \%, 4 \%$, and $5 \%)$ and sodium benzoate $(10,25$ and 50ppm) prepared earlier. The treated flowers were then packed in ventilated $(0.34 \%)$ zipper polyethylene bags (50gauge). Perforations on polyethylene bags were made with the help of Kangaro One Hole Paper Punch (hole diameter $6 \mathrm{~mm}$ ). The mouths of the bags were zipped up; the bags were stored at normal refrigerator conditions (temperature $6.5 \pm$ $5^{\circ} \mathrm{C}$ and relative humidity - 40-55\%) except treatment $\mathrm{T} 1$ (no chemical dipping only refrigerated and T9 which was kept at ambient condition (temperature $29-31^{\circ} \mathrm{C} \&$ relative humidity $49-65 \%)$.

\section{Treatments Detail}

T1: No chemical dipping

T2: Boric acid-2\%

T3: Boric acid-3\%

T4: Boric acid-4\%

T5: Boric acid-5\%

T6: Sodium benzoate-10ppm

T7: Sodium benzoate-25ppm

T8: Sodium benzoate-50ppm

T9: Control (No chemical dipping) kept at ambient condition storage

\section{Observations recorded}

The fresh weight of flowers was measured using a weighing balance. Physiological loss in weight (PLW \%), Percent of open flowers, Rotting flower (\%) and fresh flowers (\%) was calculated using the below formula

PLW $(\%)=\frac{\text { Initial flower weight }- \text { Flower weight on day of observation }}{\text { Initial flower weight }} \times 100$

Fresh flowers $(\%)=\frac{\text { No.of fresh flowers on the day of observation }}{\text { Total number of flowers }} \times 100$

Percent of open flowers $=\frac{\text { No.of open flowers on the day of observation }}{\text { Total number of flowers }} \times 100$

Rotting flower $(\%)=\frac{\text { No.of rotted or diseased flowers on the day of observation }}{\text { Total number of flowers }} \times 100$

Retention of colour was recorded daily and determined by visual observation using The Royal Horticulture Society (RHS) colour chart- mini by placing the colour chart above flowers. Acceptability was recorded daily by visual observations. It was based on a 1-9 hedonic scale suggested by Ranganna (1997) ${ }^{[12]}$, a score of 9 on a hedonic scale determines the highest acceptability, and a score of 1 is considered as least acceptable. End of shelf life or vase life was concluded when the acceptability score fell below 5 (commercially unacceptable).

\section{Statistical analysis}

The experiment included three replications for each treatment. The design adopted was a factorial Completely Randomized Design (CRD) method used for calculating the variance of the experiment. When two or more factors are tested simultaneously to see if they independently or actually interact with each other, the experiment is called factorial experiment (Mahalanobis, 1932) ${ }^{[10]}$.

\section{Result and Discussion \\ Shelf life (in days)}

The data pertaining to shelf life of tuberose florets, at cold storage conditions as influenced by post-harvest chemical treatments and packaging are presented in Table 1 .

The shelf life of tuberose florets was significantly influenced by different post-harvest treatments. The maximum shelf life of 7 days was recorded in flowers treated with 50ppm sodium benzoate and kept in polyethylene packaging (T8) under refrigerated condition followed by sodium benzoate $25 \mathrm{ppm}$ (T7) and boric acid 5\%(T5) treatment. On the other hand, minimum shelf life of 1.4 days was recorded in control (T9) flowers stored without any chemical dipping at ambient condition followed by 3.83 days in case of flowers stored in refrigerated condition (T1) without any chemical dipping.

In the present study tuberose florets dipped in 50ppm concentration of sodium benzoate (T8) remained fresh for a maximum of 7days at low temperature, compared to control (1.4 days) at ambient and T1 (3.83 days) under refrigerated condition.

The shelf life of tuberose florets increased due to sodium benzoate treatment ( 7 days) and boric acid 5\% treatment (6 days). Our results corroborate with the findings of earlier workers (Kharadi, 2009 ${ }^{[8]}$; Patel, K. 2006 ${ }^{[11]}$ ) who mentioned that increase is shelf life of flowers due to Sodium benzoate treatment may be due to its action on decreasing the $\mathrm{pH}$ (making it acidic) and creating an unsuitable environment for the growth of micro-organisms, especially bacteria and fungi. On the other hand, effect of boric acid may be attributed to its action on retention and translocation of sugars to the corolla and probably due to the anti-ethylene activity of boric acid which retards the early senescence (De and Barman. 1998) ${ }^{[4]}$. Here cold storage also plays an important role in increasing longevity of tuberose florets as compared to ambient storage condition which may be due to low temperature that reduces the entire metabolism of the tissues, slows down the respiration, transpiration and ethylene action and retards the multiplication of bacteria and fungi (Rudnicki et al, 1991) ${ }^{[14]}$. The results of the present study are in agreement with the findings of Girija et al. (2015) ${ }^{[5]}$ in Tuberose florets.

Further, the packaging of tuberose florets in polyethylene packaging has enhanced shelf life in all treatments. This effect is primarily due to initially continued metabolic activities especially respiration and transpiration of flowers, which might have led to the evolution of beneficial equilibrium of the modified atmosphere with high $\mathrm{CO} 2$ and low $\mathrm{O} 2$ and high relative humidity within the package. This might have caused the closure of stomata and minimized the respiration loss of carbohydrates as well as transpiration loss of water from flowers (Zeltzer et al., 2001) ${ }^{[18]}$.

\section{PLW\%}

The data related to change in fresh weight or PLW\% of tuberose florets at ambient temperature and low temperature as influenced by post-harvest chemical treatments and packaging is presented in Table 1 .

It is revealed from the recorded data that PLW\% of flowers significantly differed with different chemical treatments. Treatment with sodium benzoate 50ppm (1.52\%), i,e T8 
exhibited the lowest PLW followed by treatment with boric acid $5 \%(2.67 \%)$ and sodium benzoate 10ppm (3.02\%). However, flowers under control (T9) (without treatment+ ambient storage) wilted on the 2nd day of storage.

During 5th day of storage, PLW\% of flowers decreased in all treatments packed in polythene bags with lowest $(14.73 \%)$ in treatment with sodium benzoate $50 \mathrm{ppm}$ (T8) followed sodium benzoate 25ppm (T7) and boric acid 5\% (T5) (16.18\% and $18.37 \%$ respectively).

These results suggest that low-temperature storage conditions along with polythene packaging and chemical treatments had a significant influence on the shelf life of tuberose flowers. Similar findings were earlier reported by (Biao et al, 2007) ${ }^{[3]}$, who demonstrated that sodium benzoate could delay the decline time of fresh weight and flower diameter in cut rose flowers. Thamaraiselvi et al. (2010) ${ }^{[16]}$ also reported that the shelf life of jasmine extended by post-harvest dipping of jasmines in $4 \%$ in boric acid and packing in polypropylene bags and keeping them in CFB packaging has extended the shelf life of flowers by 192.32 hours kept in cold rooms at 7$80 \mathrm{C}$ with $80-85 \%$ relative humidity. These findings were also supported by Vieira et al. (2012) [17], he reported that the use of refrigeration for storage of flowers is very important because it reduces water loss, senescence, infections caused by bacteria and fungi, thus extending the shelf-life of flowers during the storage period.

\section{Retention of Colour (using a mini colour chart of RHS)}

Colour of florets were recorded RHS-155C (Greenish white) at starting of the experiment in all treatments and it remains same for all treatments till 3rd day except in control (T9) where the colour changed to RHS-155A (Pale Yellowish Green) at 1st day and RHS - 157B (Pale Yellowish Green) at 2nd and 3rd day.

\section{Percentage of open flowers}

The data related to percent of open flower at ambient temperature and low temperature as influenced by postharvest chemical treatments is presented in Table 3.

The data recorded varied significantly with different treatments. Flowers treated with sodium benzoate $25 \mathrm{ppm}$ (T7) and sodium benzoate 50ppm (T8) showed the highest opening of florets as compared to other treatments. During 3rd day of storage, flowers treated with sodium benzoate $25 \mathrm{ppm}$ (T7) showed $48.72 \%$ of opened followers followed by sodium benzoate $50 \mathrm{ppm}$ (T8) with $36.90 \%$ of opened florets as compared to control (T9) with no opening of florets.

During 5th day of storage, treatments T6, T7, and T4 exhibited more than $50 \%$ of opened flowers as compared to other treatments. On this day, the highest percentage of opened flowers were recorded in treatment with sodium benzoate $25 \mathrm{ppm}-\mathrm{T} 7(53.88 \%)$ followed by treatment with sodium benzoate $10 \mathrm{ppm}-\mathrm{T} 6(53.85 \%)$ and treatment with boric acid 4\%-T4 (51.28\%).

\section{Acceptability on a visual basis (1-9 hedonic scale)}

Acceptability score was recorded by visual observation (Table 5). During the 6th day of storage under refrigerated condition, treatment with sodium benzoate $50 \mathrm{ppm}$ (T8) shows the highest acceptability score of 7 followed by treatment with boric acid 5\% (T5) and treatment with sodium benzoate $25 \mathrm{ppm}$ (T7) with acceptability score of 6 and 5.50 respectively. The acceptability of sodium benzoate $50 \mathrm{ppm}$ was highest as the treatment delayed senescence. Similar findings were reported in carnation flowers by Baker et. al. (1977) ${ }^{[2]}$ where he demonstrated a delay in senescence by treating them with free radical scavengers such as sodium benzoate.

\section{Rotting percentage (or any disease)}

The data related to change in rotting percentage of tuberose florets at ambient temperature and low temperature as influenced by post-harvest chemical treatments are presented in Table 4.

Rotting \% of flowers significantly differed with different chemical treatments with packaging at ambient condition and cold storage conditions. Treatment with boric acid 3\% also recorded rotting percent of $2.38 \%$ on 2 nd day. After 5 thday of storage, rotting of flowers was recorded highest (11.79\%) in the case of refrigerated flowers without any chemical treatment (T1) followed by $6.56 \%$ in treatment with boric acid $2 \%$ (T2). Rotting in treatment with sodium benzoate 10ppm (T6) and boric acid 3\% (T3) was also recorded on 5th day. No rotting was observed in treatments $\mathrm{T} 7, \mathrm{~T} 8, \mathrm{~T} 4$ and $\mathrm{T} 5$ on 5 th day of storage.

Treatment with sodium benzoate 50ppm (T8) shows no rotting with maximum acceptability score followed by treatments with boric acid 5\% (T5) and sodium benzoate $25 \mathrm{ppm}$ (T7) till 6th day of storage.

The results suggested that low-temperature storage conditions along with chemical treatments had a significant influence on the rotting percentage of tuberose flowers. This result may be due to antibacterial properties of sodium benzoate (as stated by Hashemabadi et al. 2012) ${ }^{[7]}$ which has antimicrobial and anti-ethylene properties and delayed senescence in cut rose cv. Avalanche. Sodium benzoate is also known to decrease the $\mathrm{pH}$ of holding solution and making it acidic and unsuitable for the growth of micro-organisms. Thus, it helps in improving the shelf life and reduces the rotting of various flowers (Kharadi, 2009; Patel, K. 2006) ${ }^{[8,11]}$.

Thus, extension of shelf life for loose tuberose was possible up to 7 days by simple post-harvest treatments like quick dipping in sodium benzoate $(50 \mathrm{ppm})$ combined with modified atmospheric packaging (MAP) and low-temperature maintenance in the normal refrigerator. One of the major benefits of modified atmosphere packaging (MAP) is the prevention or retardation of flower senescence and associated with physiological and biochemical changes The florets with polyethylene lining had a less physiological loss in weight (PLW) with increased freshness as because the said packaging material could retain higher moisture content leading to delay in the appearance of senescence (Madaiah and Reddy, 1992) [9]. This was probably due to the modified atmosphere condition of gaseous composition and high relative humidity created by the polyethylene lining (Anzeuto and Rizvi, 1985) [1].

Due to maintenance of lower temperature along with high humidity the rate of moisture loss from the flower was reduced in the present investigation, leading to a reduction in the physiological loss in weight (PLW) and maintenance of freshness. The rate of respiration and other enzymatic activities were also probably much lower, thereby delaying the senescence process in the florets. These findings accorded with those of other researchers (Madaiah and Reddy, 1992) [9] who reported the extension of storage life of flowers by using a lower temperature. According to Reid (1992) ${ }^{[13]}$, reduction 
of the metabolism was possible by lowering the temperature of harvesting ornamentals. Besides, metabolism and the senescence process underlay, the post-harvest life of harvested ornamentals was also affected by the loss of water, attack by micro-organisms, loss of respirable substrate, and undesirable growth and development.

In conclusion, the results of the present investigation revealed that flowers treated with sodium benzoate 50ppm exhibited maximum shelf life (7 days), minimum loss of fresh weight $(19.30 \%)$, and the highest proportion of fresh flowers $(68.65 \%)$ with greater acceptability. The next best treatment was identified as boric acid 5\% which maintained shelf life of loose tuberose florets up to 6 days, with less PLW\% (23.02\%) and second-highest proportion of fresh flowers (62.17\%) with optimum acceptability.

Thus, the extension of shelf life for loose tuberose was possible up to 7 days by simple post-harvest treatments like quick dipping in sodium benzoate $(50 \mathrm{ppm})$ combined with modified atmospheric packaging (MAP) and low-temperature maintenance in the normal refrigerator. In this treatment combination, sodium benzoate acted as an acidifying agent by releasing benzoic acid (as shown in Fig 1. below) and checked the growth of microorganisms in low $\mathrm{pH}$ (4 to 4.5).

$$
\text { sodium benzoate }+\mathrm{H}_{2} \mathrm{O} \longrightarrow+\mathrm{NaOH}
$$

$\mathrm{NaC}_{7} \mathrm{H}_{5} \mathrm{O}_{2}+\mathrm{H}_{2} \mathrm{O} \rightarrow \mathrm{C}_{7} \mathrm{H}_{6} \mathrm{O}_{2}+\mathrm{NaOH}$ (Shahmohammadi et al. 2016) ${ }^{[15]}$.

Fig 1: The chemical reaction between Sodium benzoate and water to form Benzoic acid and sodium hydroxide.

Also, the use of MAP helped in retardation of flower senescence and associated physiological and biochemical changes in storage. This was probably due to the modified atmosphere condition of gaseous composition and high relative humidity created by the polyethylene packaging. Finally, the low temperature in the normal refrigerator along with high humidity (due to polyethylene packaging) the rate of moisture loss from the flower was also reduced leading to a reduction in the physiological loss in weight (PLW) and maintenance of freshness. The rate of respiration and other enzymatic activities were also much lower in refrigerator resulting in delayed senescence of the florets.

Thus, it may be concluded that loose tuberose flowers treated with sodium benzoate $50 \mathrm{ppm}$ and packed in polyethylene zipper packs at 50 gauge stored at refrigerated condition maintained good keeping quality up to 7 days.

Table 1: Shelf life (days) and PLW\% of tuberose florets as influenced by different chemicals at refrigerated conditions and ambient conditions (without chemicals).

\begin{tabular}{|c|c|c|c|c|c|c|c|c|}
\hline \multirow{3}{*}{ Treatments } & \multirow{3}{*}{ Shelf life (days) } & \multicolumn{7}{|c|}{ Physiological loss of weight (\%) } \\
\hline & & \multicolumn{7}{|c|}{ Days After Storage } \\
\hline & & 1 & 2 & 3 & 4 & 5 & 6 & 7 \\
\hline $\mathrm{T} 1$ - (only refrigerated) & 3.83 & $\begin{array}{c}8.18 \\
(16.62)\end{array}$ & $\begin{array}{c}13.92 \\
(21.91)\end{array}$ & $\begin{array}{c}18.28 \\
(25.31)\end{array}$ & $\begin{array}{c}23.53 \\
(29.02)\end{array}$ & $\begin{array}{c}25.85 \\
(30.56)\end{array}$ & $\begin{array}{c}28.18 \\
(32.06)\end{array}$ & $\begin{array}{c}29.58 \\
(32.95)\end{array}$ \\
\hline T2-BA $2 \%$ & 5.00 & $\begin{array}{c}4.67 \\
(12.48)\end{array}$ & $\begin{array}{c}11.70 \\
(20.00)\end{array}$ & $\begin{array}{c}17.15 \\
(24.46)\end{array}$ & $\begin{array}{c}19.88 \\
(26.48)\end{array}$ & $\begin{array}{c}21.17 \\
(27.39)\end{array}$ & $\begin{array}{c}23.68 \\
(29.12)\end{array}$ & $\begin{array}{c}25.78 \\
(30.51)\end{array}$ \\
\hline T3-BA 3\% & 5.00 & $\begin{array}{c}5.20 \\
(13.18) \\
\end{array}$ & $\begin{array}{c}10.83 \\
(19.21) \\
\end{array}$ & $\begin{array}{c}15.38 \\
(23.09) \\
\end{array}$ & $\begin{array}{c}17.55 \\
(24.77) \\
\end{array}$ & $\begin{array}{c}19.47 \\
(26.18) \\
\end{array}$ & $\begin{array}{c}22.88 \\
(28.58) \\
\end{array}$ & $\begin{array}{c}25.00 \\
(30.00) \\
\end{array}$ \\
\hline T4-BA $4 \%$ & 5.50 & $\begin{array}{c}3.75 \\
(11.17)\end{array}$ & $\begin{array}{c}7.60 \\
(16.00)\end{array}$ & $\begin{array}{c}12.67 \\
(20.85)\end{array}$ & $\begin{array}{c}15.48 \\
(23.17)\end{array}$ & $\begin{array}{c}19.27 \\
(26.04)\end{array}$ & $\begin{array}{c}21.88 \\
(27.89)\end{array}$ & $\begin{array}{c}23.88 \\
(29.25)\end{array}$ \\
\hline T5-BA $5 \%$ & 6.00 & $\begin{array}{c}2.67 \\
(9.40)\end{array}$ & $\begin{array}{c}5.78 \\
(13.91)\end{array}$ & $\begin{array}{l}11.10 \\
19.46\end{array}$ & $\begin{array}{c}14.53 \\
(22.41)\end{array}$ & $\begin{array}{c}18.37 \\
(25.38)\end{array}$ & $\begin{array}{c}20.52 \\
(26.94)\end{array}$ & $\begin{array}{c}23.02 \\
(28.67) \\
\end{array}$ \\
\hline T6- SB 10ppm & 5.50 & $\begin{array}{c}3.02 \\
(10.01)\end{array}$ & $\begin{array}{c}7.72 \\
(16.13)\end{array}$ & $\begin{array}{c}13.30 \\
(21.39)\end{array}$ & $\begin{array}{c}18.18 \\
(25.24)\end{array}$ & $\begin{array}{c}20.97 \\
(27.25)\end{array}$ & $\begin{array}{c}24.40 \\
(29.60)\end{array}$ & $\begin{array}{c}24.93 \\
(29.95)\end{array}$ \\
\hline T7- SB 25ppm & 6.00 & $\begin{array}{c}3.10 \\
(10.14)\end{array}$ & $\begin{array}{c}7.43 \\
(15.82)\end{array}$ & $\begin{array}{c}12.25 \\
(20.49)\end{array}$ & $\begin{array}{c}14.27 \\
(22.19)\end{array}$ & $\begin{array}{c}16.18 \\
(23.72)\end{array}$ & $\begin{array}{c}19.07 \\
(25.89)\end{array}$ & $\begin{array}{c}21.03 \\
(27.30)\end{array}$ \\
\hline T8- SB 50ppm & 7.00 & $\begin{array}{c}1.52 \\
(7.08)\end{array}$ & $\begin{array}{c}4.82 \\
(12.68)\end{array}$ & $\begin{array}{c}9.65 \\
(18.10)\end{array}$ & $\begin{array}{c}11.35 \\
(19.69)\end{array}$ & $\begin{array}{c}14.73 \\
(22.57)\end{array}$ & $\begin{array}{c}16.85 \\
(24.24)\end{array}$ & $\begin{array}{c}19.30 \\
(26.06)\end{array}$ \\
\hline T9- control & 1.40 & $\begin{array}{c}9.50 \\
(17.95)\end{array}$ & $\begin{array}{c}19.33 \\
(26.08)\end{array}$ & $\begin{array}{c}24.33 \\
(29.55)\end{array}$ & N/A & N/A & N/A & N/A \\
\hline $\operatorname{SEm}( \pm)$ & 0.07 & 0.24 & 0.33 & 0.36 & 0.33 & 0.35 & 0.36 & 0.42 \\
\hline $\mathrm{Cd}$ at $5 \%$ & 0.19 & 0.72 & 1.00 & 1.09 & 0.99 & 1.05 & 1.08 & 1.27 \\
\hline
\end{tabular}

*BA - Boric acid, SB - Sodium benzoate, T9- control (ambient condition storage), N/A- not available, *Parenthesis represents transformed values (arcsine).

Table 2: Percent of fresh flowers as influenced by different chemicals at refrigerated conditions and ambient conditions (without chemicals).

\begin{tabular}{|c|c|c|c|c|c|c|}
\hline \multirow{3}{*}{ Treatments } & \multicolumn{6}{|c|}{ Percent of fresh flowers } \\
\hline & \multicolumn{6}{|c|}{ Days After Storage } \\
\hline & 1 & 2 & 3 & 4 & 5 & 6 \\
\hline T1- (only refrigerated) & $\begin{array}{c}92.64 \\
(74.26)\end{array}$ & $\begin{array}{c}87.86 \\
(69.61) \\
\end{array}$ & $\begin{array}{c}83.07 \\
(65.70) \\
\end{array}$ & $\begin{array}{c}61.02 \\
(51.37)\end{array}$ & $\begin{array}{c}51.45 \\
(45.83) \\
\end{array}$ & $\begin{array}{c}36.75 \\
(37.32) \\
\end{array}$ \\
\hline T2-BA $2 \%$ & $\begin{array}{c}97.77 \\
(81.43) \\
\end{array}$ & $\begin{array}{c}91.21 \\
(72.75) \\
\end{array}$ & $\begin{array}{c}84.65 \\
(66.93) \\
\end{array}$ & $\begin{array}{c}69.55 \\
(56.51) \\
\end{array}$ & $\begin{array}{c}54.05 \\
(47.32) \\
\end{array}$ & $\begin{array}{r}38.70 \\
(38.47) \\
\end{array}$ \\
\hline T3-BA 3\% & $\begin{array}{c}97.77 \\
(81.43)\end{array}$ & $\begin{array}{c}95.39 \\
(77.60) \\
\end{array}$ & $\begin{array}{c}85.79 \\
(67.85) \\
\end{array}$ & $\begin{array}{c}75.63 \\
(60.42) \\
\end{array}$ & $\begin{array}{c}63.65 \\
(52.92) \\
\end{array}$ & $\begin{array}{c}46.67 \\
(43.09) \\
\end{array}$ \\
\hline T4-BA 4\% & $\begin{array}{c}97.61 \\
(81.12)\end{array}$ & $\begin{array}{c}92.27 \\
(73.86)\end{array}$ & $\begin{array}{c}84.55 \\
(66.85)\end{array}$ & $\begin{array}{c}76.83 \\
(61.23)\end{array}$ & $\begin{array}{c}59.00 \\
(50.18)\end{array}$ & $\begin{array}{c}48.72 \\
(44.27)\end{array}$ \\
\hline T5-BA $5 \%$ & $\begin{array}{c}97.22 \\
(80.40) \\
\end{array}$ & $\begin{array}{c}94.44 \\
(76.36) \\
\end{array}$ & $\begin{array}{c}89.10 \\
(70.72) \\
\end{array}$ & $\begin{array}{c}86.53 \\
(68.47) \\
\end{array}$ & $\begin{array}{c}70.30 \\
(56.98) \\
\end{array}$ & $\begin{array}{r}62.17 \\
(52.04) \\
\end{array}$ \\
\hline T6- SB 10ppm & 97.61 & 92.67 & 87.91 & 73.25 & 68.31 & 51.28 \\
\hline
\end{tabular}




\begin{tabular}{|c|c|c|c|c|c|c|}
\hline & $(81.12)$ & $(74.29)$ & $(69.65)$ & $(58.86)$ & $(55.74)$ & $(45.73)$ \\
\hline T7- SB 25ppm & $\begin{array}{c}95.05 \\
(77.14)\end{array}$ & $\begin{array}{c}92.27 \\
(73.86)\end{array}$ & $\begin{array}{c}89.87 \\
(71.44)\end{array}$ & $\begin{array}{c}82.15 \\
(65.01)\end{array}$ & $\begin{array}{c}78.42 \\
(62.32)\end{array}$ & $\begin{array}{c}54.06 \\
(47.33)\end{array}$ \\
\hline T8- SB 50ppm & $\begin{array}{c}100 \\
(90.00)\end{array}$ & $\begin{array}{c}100.00 \\
(90.00)\end{array}$ & $\begin{array}{c}94.84 \\
(76.87)\end{array}$ & $\begin{array}{c}92.06 \\
(73.63)\end{array}$ & $\begin{array}{c}89.28 \\
(70.89)\end{array}$ & $\begin{array}{c}68.65 \\
(55.95)\end{array}$ \\
\hline T9- control & $\begin{array}{c}72.05 \\
(58.09)\end{array}$ & $\begin{array}{c}34.92 \\
(36.22)\end{array}$ & 0.00 & N/A & N/A & N/A \\
\hline SEm( \pm Cd at 5\% & 4.25 & 1.65 & 2.22 & 1.18 & 1.60 & 2.68 \\
\hline
\end{tabular}

*BA - Boric acid, SB - Sodium benzoate, T9- control (ambient condition storage), N/A- not available, *Parenthesis represents transformed values (arcsine).

Table 3: Percent of open florets as influenced by different chemicals at refrigerated conditions and ambient conditions (without chemicals).

\begin{tabular}{|c|c|c|c|c|c|c|c|}
\hline \multirow{2}{*}{ Treatments } & \multicolumn{7}{|c|}{ Percent of open florets } \\
\cline { 2 - 8 } & \multicolumn{9}{|c|}{ Days After Storage } \\
\cline { 2 - 8 } & 1 & 2 & 3 & 4 & 5 & 6 & 7 \\
\hline T1- (only refrigerated) & $0 *$ & 24.62 & 24.62 & 24.62 & 29.4 & 17.26 & $0 * *$ \\
\hline T2-BA 2\% & 21.65 & 21.65 & 21.65 & 40.92 & 40.92 & 25.84 & $0 * *$ \\
\hline T3-BA 3\% & 2.22 & 21.59 & 21.59 & 38.73 & 38.73 & 36.51 & $0 * *$ \\
\hline T4-BA 4\% & 7.72 & 18.22 & 28.11 & 51.28 & 51.28 & 33.46 & 5.13 \\
\hline T5-BA 5\% & 2.56 & 13.46 & 21.58 & 43.16 & 43.16 & 35.26 & 7.69 \\
\hline T6- SB 10ppm & 7.69 & 23.08 & 23.08 & 48.90 & 48.90 & 34.24 & 2.380 \\
\hline T7-SB 25ppm & 22.77 & 43.77 & 48.72 & 53.88 & 53.88 & 43.77 & 5.34 \\
\hline T8- SB 50ppm & 18.65 & 34.52 & 36.9 & 47.22 & 47.22 & 34.13 & 4.24 \\
\hline T9- control & 39.52 & 23.33 & $0 * *$ & N/A & N/A & N/A & N/A \\
\hline SEm( \pm Cd at 5\% & 2.50 & 2.81 & 2.14 & 2.88 & 2.69 & 3.30 & 3.50 \\
\hline
\end{tabular}

BA - Boric acid, SB - Sodium benzoate, T9- control (ambient condition storage)

NS- Non-significant, N/A- not available due to end of shelf life

(*) indicates unopened bud stage, $(* *)$ indicates closed due to desiccation

Table 4: Rotting (\%) of tuberose florets as influenced by different chemicals at refrigerated conditions and ambient conditions (without chemicals).

\begin{tabular}{|c|c|c|c|c|c|c|c|}
\hline \multirow{3}{*}{ Treatments } & \multicolumn{7}{|c|}{ Rotting (\%) } \\
\hline & \multicolumn{7}{|c|}{ Days After Storage } \\
\hline & 1 & 2 & 3 & 4 & 5 & 6 & 7 \\
\hline T1- (only refrigerated) & $0.00(0.71)$ & $2.22(1.37)$ & $2.22(1.37)$ & $6.67(2.68)$ & $11.79(3.51)$ & $16.58(4.13)$ & $16.58(4.13)$ \\
\hline T2-BA $2 \%$ & $0.00(0.71)$ & $0.00(0.71)$ & $1.96(1.57)$ & $6.56(2.66)$ & $6.56(2.66)$ & $6.56(2.66)$ & $12.71(3.63)$ \\
\hline T3-BA 3\% & $0.00(0.71)$ & $2.38(1.39)$ & $2.38(1.39)$ & $2.38(1.39)$ & $2.38(1.39)$ & $2.38(1.39)$ & $2.38(1.39)$ \\
\hline T4-BA 4\% & $0.00(0.71)$ & $0.00(0.71)$ & $0.00(0.71)$ & $0.00(0.71)$ & $0.00(0.71)$ & $0.00(0.71)$ & $9.71(3.20)$ \\
\hline T5-BA 5\% & $0.00(0.71)$ & $0.00(0.71)$ & $0.00(0.71)$ & $0.00(0.71)$ & $0.00(0.71)$ & $0.00(0.71)$ & $0.00(0.71)$ \\
\hline T6- SB 10ppm & $0.00(0.71)$ & $0.00(0.71)$ & $0.00(0.71)$ & $0.00(0.71)$ & $2.38(1.39)$ & $2.38(1.39)$ & $4.76(2.29)$ \\
\hline T7- SB 25ppm & $0.00(0.71)$ & $0.00(0.71)$ & $0.00(0.71)$ & $0.00(0.71)$ & $0.00(0.71)$ & $0.00(0.71)$ & $0.00(0.71)$ \\
\hline T8- SB 50ppm & $0.00(0.71)$ & $0.00(0.71)$ & $0.00(0.71)$ & $0.00(0.71)$ & $0.00(0.71)$ & $0.00(0.71)$ & $0.00(0.71)$ \\
\hline T9- control & $2.22(1.37)$ & $4.60(2.05)$ & $6.98(2.73)$ & N/A & N/A & N/A & N/A \\
\hline $\operatorname{SEm}( \pm)$ & 0.22 & 0.39 & 0.38 & 0.51 & 0.40 & 0.49 & 0.54 \\
\hline $\mathrm{Cd}$ at $5 \%$ & NS & NS & 1.21 & NS & 1.20 & 1.24 & 1.63 \\
\hline
\end{tabular}

*BA - Boric acid, SB - Sodium benzoate, T9- control (ambient condition storage)

NS- Non-significant, N/A- not available due to end of shelf life, *Parenthesis represents transformed values (square root).

Table 5: Acceptability scores of tuberose florets as influenced by different chemicals at refrigerated conditions and ambient conditions (without chemicals).

\begin{tabular}{|c|c|c|c|c|c|c|c|}
\hline \multirow{2}{*}{ Treatments } & \multicolumn{7}{|c|}{ Acceptability score (1-9 hedonic scale) } \\
\cline { 2 - 8 } & \multicolumn{9}{|c|}{ Days After Storage } \\
\cline { 2 - 8 } & $\mathbf{1}$ & $\mathbf{2}$ & $\mathbf{3}$ & $\mathbf{4}$ & $\mathbf{5}$ & $\mathbf{6}$ & $\mathbf{7}$ \\
\hline T1- (only refrigerated) & 9.00 & 8.50 & 7.50 & 7.00 & 4.50 & 3.00 & 1.00 \\
\hline T2-BA 2\% & 9.00 & 8.50 & 8.00 & 7.00 & 6.00 & 4.00 & 1.50 \\
\hline T3-BA 3\% & 9.00 & 9.00 & 8.20 & 7.50 & 6.50 & 4.50 & 2.00 \\
\hline T4-BA 4\% & 9.00 & 9.00 & 8.37 & 7.50 & 6.50 & 5.00 & 2.50 \\
\hline T5-BA 5\% & 9.00 & 9.00 & 8.50 & 8.00 & 7.00 & 6.00 & 3.50 \\
\hline T6- SB 10ppm & 9.00 & 9.00 & 8.30 & 8.00 & 6.67 & 4.67 & 3.00 \\
\hline T7- SB 25ppm & 9.00 & 9.00 & 8.50 & 8.00 & 6.83 & 5.50 & 3.67 \\
\hline T8- SB 50ppm & 9.00 & 9.00 & 8.70 & 8.50 & 7.50 & 7.00 & 4.67 \\
\hline T9- control & 7.30 & 4.00 & 1.00 & N/A & N/A & N/A & N/A \\
\hline SEm \pm - & 0.05 & 0.03 & 0.02 & 0.07 & 0.08 & 0.06 & 0.08 \\
\hline Cd at 5\% & 0.15 & 0.10 & 0.07 & 0.00 & 0.25 & 0.18 & 0.25 \\
\hline
\end{tabular}

*BA - Boric acid, SB - Sodium benzoate, T9- control (ambient condition storage), N/A- not available 


\section{Reference}

1. Anzueto CR, Rizvi SSH. Individual packaging of apples for shelf life extension. Journal of Food Science. 1985; 50(4):897-900.

2. Baker JE, Wang CY, Lieberman M, Hardenburg R. Delay of senescence in carnations by a rhizobitoxine analog and sodium benzoate. Hort. Science. 1977; 12:3839.

3. Biao W, Jian W, Jia YL, Suting L. Anhui Agric. Sci., (Abstract), 2007.

4. De LC, Barman D. Postharvest behavior of cut Tuberose Spikes as Influenced by Chemicals. Journal of Ornamental Horticulture. 1998; 1(2):66-68.

5. Girija CK, Nair SA, Srinivas M. Effect of precooling and chemical preservatives on post harvest longevity of tuberose (Polianthes tuberosa L.) florets. International Journal of Agriculture, Environment and Biotechnology. New Delhi Publishers. India. 2015; 8(1):65-68.

6. Hardenburg RE. The commercial storage of fruits, vegetables, and florist. and nursery stocks. USDA Agriculture Handbook, 1990, 66.

7. Hashemabadi D, Imani MH, Kaviani B, Zarchini M. Effect of sodium benzoate on longevity and ethylene production in cut rose (Rosa hybrida L. cv. Avalanche) flower. European Journal of Experimental Biology. 2012; 2(6):2485-2488.

8. Kharadi DM. Effect of salicylic acid on growth, flowering and post harvest shelf life of Gaillardia pulchella Fouger and Centaurea cyanus Linn. M. Phil. Dissertation, Gujarat University, Gujarat, 2009.

9. Madaiah D, Reddy TV. Influence of polyethylene packaging on the postharvest life of tuberose (cv. Single) florets. Karnataka Journal of Agricultural Science. 1994; 7(2):154-157.

10. Mahalanobis PC. Statistical notes for Agricultural workers. NO. 4. Rice and potato Experiment at Sriniketan. Indian Journal of Agricultural Science. 1932; 2:694-703.

11. Patel KD. Studies on effect of Maleic Hydrazide on Flowering and Post harvest shelf life of Calendula officinalis L. and Tagetes erecta L. M. Phil. Dissertation, Gujarat University, Gujarat, 2006.

12. Ranganna S. Handbook of Analysis and Quality Control for Fruits and Vegetable Products. 2nd ed., Tata Mac Graw Hill Publication Co., New Delhi, 1997, 112.

13. Reid MS. Post-harvest technology of horticultural crops. 2nd Edition. Ed. A.A. Kader. UCDANR Pub. 1992; 3311:201-209.

14. Rudnicki RM, Nowak J, Goszczynska D. Cold storage and transpiration for cut flowers, cuttings and potted plants. Acta Horticulture. 1991; 298:225-231.

15. Shahmohammadi M, Javadi M, Nassiri-Asl M. An Overview on the Effects of Sodium Benzoate as a Preservative in Food Products. Biotech Health Sci, 2016, 2-3.

16. Thamavaiselvi SP, Jawaharlal M, Ganga M, Varadhavaju N. Packaging technology for long term storage of Jasmine (Jasminum sambac Ait.) flowers. Journal of Ornamental Horticulture. 2010; 13(3):171-181.

17. Vieira MR, Costa PN, Santos CMG, Fernandez LM, Paes $\mathrm{RN}$, Allan A et al. Effect of refrigeration on post-harvest flowers. African Journal of Biotechnology. 2012; 11(67):13065-13068
18. Zeltzer S, Meir S, Mayak S. Modified atmosphere packaging (MAP) for long- term shipment of cut flowers. Acta Horticulturae. 2001; 553:631-634. 